\title{
Influence of altitude on eco-phytochemical parameters of Peganum harmala, Sophora alopecuriodes and Ziziphora clinopodioides Lam in rangelands of northern Iran
}

\author{
M.R. KHATAMI MOGHADDAM ${ }^{1}$, H. FALLAH ${ }^{1}$, Y. NIKNEJAD $^{1}$ and S. DASTAN ${ }^{2}$ \\ ${ }^{I}$ Department of Agronomy, Ayatollah Amoli Branch, Islamic Azad University, Amol, Iran. \\ ${ }^{2}$ Departmant of Biosafety and Genetic Engineering, Agricultural Biotechnology \\ Research Institute of Iran (ABRII), Karaj, Iran. \\ *Corresponding Author : hormozfalaf@gmail.com
}

\begin{abstract}
Northern Iran especially Alborz Mountain range is one of the most important floristic regions of Iran, which has high medicinal plant biodiversity. Research areas were located between the northern part of the Alborz Mountains range and south of the Caspian Sea in northern Iran, west of the Mediterranean. Selection of rangelands for ecological survey was carried out according to the climate diversity of Amol County in Mazandaran province during 2018 growing season. Three altitude in the regions including Rineh (1800 m above mean sea level), Polur (2300 m AMSL) and Lar Plain (2800 m AMSL) for each herbal medicinal plant (Sophora alopecuriodes, Peganum harmala and Ziziphora clinopodioides Lam) were chosen as treatment. The results showed that plant fresh weight and plant dry matter of Peganum harmala, Sophora alopecuriodes and Ziziphora clinopodioides was decreased with enhance of altitude from sea level. Essential oil yield of Peganum harmala and Sophora alopecuriodes enhanced by increase of altitude, but for Ziziphora clinopodioidest, with increase of altitude the essential oil yield was decreased. In Peganum harmala, only benzaldehyd 2-amino was enhanced with increase of altitude from $1800 \mathrm{~m}$ to $2800 \mathrm{~m}$ AMSL, but eicosane was decreased by altitude increasing. For Sophora alopecuriodes the most amount of sophoramine and adenocarpine was obtained in $1800 \mathrm{~m}$ above sea level, but sophocarpine and vinylphenol shows the highest rates in $2800 \mathrm{~m} \mathrm{AMSL}$. For Ziziphora clinopodioides, the highest amount of alpha.-thujene, camphene and sabinene was observed in altitude of $1800 \mathrm{~m}$ above sea level. But, alpha.-pinene, 2-beta.-pinene, beta.-myrcene and 3-octanol in altitude of $2800 \mathrm{~m} \mathrm{AMSL}$ demonstrated higher rates. As a result, natural ecosystems, altitude above sea level are among the main determinants of the qualitative and plant quantitative parameters of medicinal plants.
\end{abstract}

Keywords: Altitude, essential oil, yield, medicinal plants, rangeland

Due to various climates, the Iranian plateau has a wide range of plant species. Alborz altitudes are located between two European, Siberian and Iranian-Turanian vegetative regions. It is one of the most important floristic regions of Iran, which has high biodiversity (Mozaffarian, 2013). Due to the geographical location, climate diversity, ecological diversity, different topographical conditions and high altitude of this region, there are relatively favorable medicinal plants rangelands that are preserved based on the accurate recognition of the components of these ecosystems and the awareness of the interactions between living and non-living ecological factors on vegetation in these regions. With the right planning, they can have a special place in terms of treatment, medicine, food, cosmetics, and hygiene, especially economic ones (Mozaffarian, 2013). Therefore, the collection and identification of plant species of this region makes it possible to protect these gene reserves and identify them.

Three medicinal plant including sophora (Sophora alopecuriodes), wild Syrian or harmal (Peganum harmala) and Ziziphora (Ziziphora clinopodioides Lam) were considered in this region. Sophora var. alopecuroides (Leguminosae) is an herbal medicinal plant widely distributed in east, western, south-west and central Asia (Kianbakht and Dabbaghian 2016).

Wild Syrian rue (Peganum harmala L. family Zygophyllaceae) is a perennial, glabrous herbal medicinal plant which grows spontaneously in semi-arid conditions, steppe areas and sandy soils, native to eastern Mediterranean region (Berdai et al., 2014). It is a shrub, 0.3-0.8 $\mathrm{m}$ height with 
Table 1: Description of the geographical coordinate, average temperature (during 2018 growing season) and soil properties (0$30 \mathrm{~cm}$ ) in altitude of 1800, 2300 and $2800 \mathrm{~m}$ above sea level in Rineh, Polur and Lar regions, respectively.

\begin{tabular}{|c|c|c|c|}
\hline Description & $\begin{array}{l}\text { Rineh region (altitude of } \\
1800 \mathrm{~m} \text { above sea level) }\end{array}$ & $\begin{array}{l}\text { Polur region (altitude of } \\
2300 \mathrm{~m} \text { above sea level) }\end{array}$ & $\begin{array}{c}\text { Lar region (altitude of } \\
2800 \mathrm{~m} \text { above sea level) }\end{array}$ \\
\hline Geographical & $35^{\circ} 52^{\prime} 53^{\prime \prime} \mathrm{N}$ & $35^{\circ} 50^{\prime} 31^{\prime \prime} \mathrm{N}$ & $35^{\circ} 58^{\prime} 24^{\prime \prime} \mathrm{N}$ \\
\hline coordinate & $52^{\circ} 10^{\prime} 407^{\prime \prime} \mathrm{E}$ & $52^{\circ} 02^{\prime} 55^{\prime \prime} \mathrm{E}$ & $51^{\circ} 58^{\prime} 49^{\prime \prime} \mathrm{E}$ \\
\hline Altitude above sea level & $1800 \mathrm{~m}$ & $2300 \mathrm{~m}$ & $2800 \mathrm{~m}$ \\
\hline Average temperature $\left({ }^{\circ} \mathrm{C}\right)$ & 26.0 & 22.0 & 18.0 \\
\hline
\end{tabular}

\section{Soil properties}

\section{Peganum harmala}

Soil texture

$\mathrm{EC}\left(\mathrm{dSm}^{-1}\right)$

$\mathrm{pH}$

Organic matter (\%)

N (\%)

Phosphorus ( $\mathrm{mg} \mathrm{kg}^{-1}$ )

Potassium ( $\mathrm{mg} \mathrm{kg}^{-1}$ )

\section{Sophoraalopecuriodes}

Soil texture

$\mathrm{EC}\left(\mathrm{dSm}^{-1}\right)$

$\mathrm{pH}$

Organic matter (\%)

N (\%)

Phosphorus (mg kg-1)

Potassium ( $\mathrm{mg} \mathrm{kg}^{-1}$ )
Silt

1.04

7.61

1.01

0.04

6.2

375

Silt

1.04

7.61

1.01

0.04

6.20

375
Silt

0.83

7.57

0.67

0.07

12

285

Silt loam

0.82

7.53

1.50

0.07

23.40

385
Silt loam

0.76

7.71

3.67

0.17

20.9

612

Clay loam

0.85

7.22

3.37

0.16

14.40

452

\section{Ziziphora clinopodioides Lam}

Soil texture

$\mathrm{EC}\left(\mathrm{dSm}^{-1}\right)$

$\mathrm{pH}$

Organic matter (\%)

N (\%)

Phosphorus (mg kg ${ }^{-1}$ )

Potassium ( $\mathrm{m} \mathrm{kg}^{-1}$ )
Silt loam

0.57

7.69

1.07

0.05

17.5

239
Silt

0.53

7.79

1.41

0.06

9.6

60
Silt loam

0.88

7.36

2.33

0.11

23.6

294
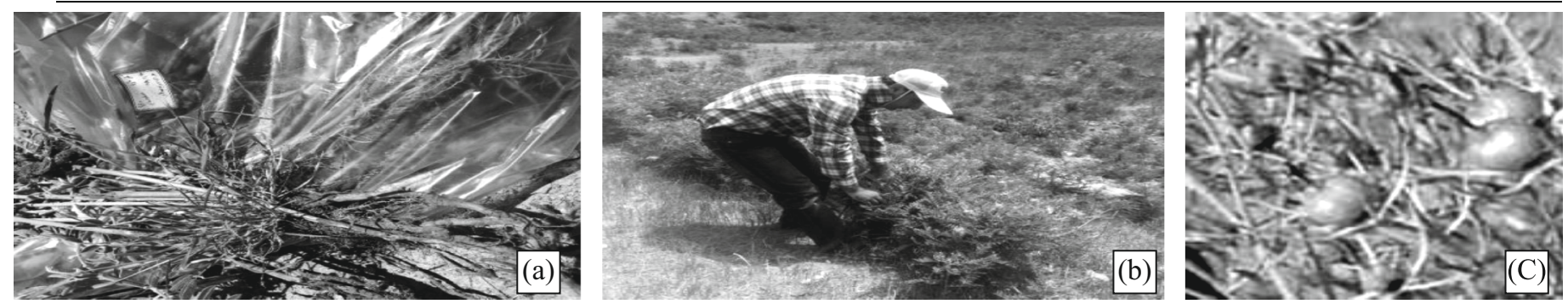

Fig. 1: Description of the medicinal plant photo: Peganum harmala (a), Sophora alopecuriodes (b) and Ziziphora clinopodioides Lam (c). 
short creeping roots, white flowers and round seed capsules carrying more than 50 seeds. This plant is well-known in Iran and is widely distributed and used as a medicinal plant in Central Asia, North Africa and Middle East (Wanntorp and Louis, 2011). Various parts of $P$. harmala including its seeds, fruits, root, and bark, have been used as folk medicine for a long time in Iran and other countries (Moloudizargari et al. 2013).

Ziziphora clinopodioide Lam is a traditional medicinal plant widely distributed in Turkey, China, Mongolia, Kyrgyzstan and Kazakhstan (Liu, 1985). This plant is widely used in Iranian traditional medicine for gastrointestinal disorders, carminative, sedative, anti-inflammatory, antiemetic and antiseptic substance in food (Maya, 2011). Ziziphora is as an edible medicinal plant and its leaves, flowers and stems as a wild vegetable or an additive in food for richer aroma and flavor (Ding et al., 2014).

No phyto-chemical and biological data on these three medicinal plant growing in Iran were found in a literature survey. Thus, in the course of our ongoing studies, we aimed at evaluating eco-phyto-chemical parameters of Peganum harmala, Sophora alopecuriodes and Ziziphora clinopodioides Lam in rangelands of northern Iran.

\section{MATERIAL AND METHODS}

\section{Description of the region}

Research areas were located between the northern part of the Alborz Mountains range and south of the Caspian Sea in northern Iran, west of the Mediterranean. Amol County is located in Mazandaran province in northern Iran during 2018 growing season. These surveys were conducted in three regions with different altitude above sea level (Table 1). Geographical coordinate and soil properties of survey regions are shown in Table 1. Rineh is a city and the capital of Larijan District, in Amol County, Mazandaran Province, Iran. Polur is a village on the Haraz River in Bala Larijan Rural District, Larijan District, Amol County, Mazandaran Province, Iran. Lar plain is located in the foothills of Damavand Peak, in the northern and northeastern part of the Larijan District of Amol County and its south and southwestern part in Lavasanat region, Shemiran County, Tehran province.

According to the climatic parameters and topography, these regions are divided into two climate Caspian humid weather and mountain mild weather. In terms of flora, plants are divided into two plain and slope areas, the altitude of which varies from 2200 to $3870 \mathrm{~m}$ above sea level. The average 15- years rainfall in these regions is about $528 \mathrm{~mm}$ per year, most of which is in the form of snow. The average minimum temperature is $-17.8^{\circ} \mathrm{C}$ in February and the average maximum temperature is $25.9^{\circ} \mathrm{C}$ in August. The Ombrothermic diagram of these areas shows a fairly long dry period from mid-May to mid-October. More description of each site is shown in Table 1 .

\section{Data collection and statistical experiment}

Selection of rangelands for ecological survey was carried out according to the climate diversity of Mazandaran province. After determining growth distribution areas of the plants to evaluate the ecological factors, three mountainous regions in Larijan Distinct were selected.

After preliminary evaluation, each medicinal plant was collected in each region. The surveyed region and distribution of these plants were identified and selected according to the resources of the Iranian flora library such as Flora Iranica and Flora of the Champion. After that, three ecosystems with the most ecological diversity were identified which includes Rineh, Polur and Lar Plain. The experiment was carried out in a randomized complete blocks design (RCBD) with three replications. Three altitude including Rineh (1800 $\mathrm{m}$ above sea level), Polur (2300 m above sea level) and Lar Plain (2800 m above sea level) for each herbal medicinal plant (Sophora alopecuriodes, Peganum harmala and Ziziphora clinopodioides Lam) were chosen as treatment (Fig. 1a-c).

In each region, a number of rangelands, which are as simple as possible, reflect a pattern of the reality of the propagation and development of these species in nature, were examined at various times and field plots visits. After primary identifying and determining the boundaries of the studied areas, the method for evaluating the reproductive stage of the species was studied using randomized plots. In this method, 10 plots were randomly located in each area and plant traits into plots were measured. Based on the phenological stages before flowering and after flowering, one sample with three replications was randomly harvested.

\section{Measurements}

Plant height and root length were measured in each plot. The shoot and root weight were also measured by counting two meters of quadrat in the laboratory. After that, to determine the dry weight of each tissue (shoot and root) of the plant were placed for several days in the indirect environment of sunlight. Then, each tissue weighed again after drying under shade conditions. In order to determine the essential oil, the 


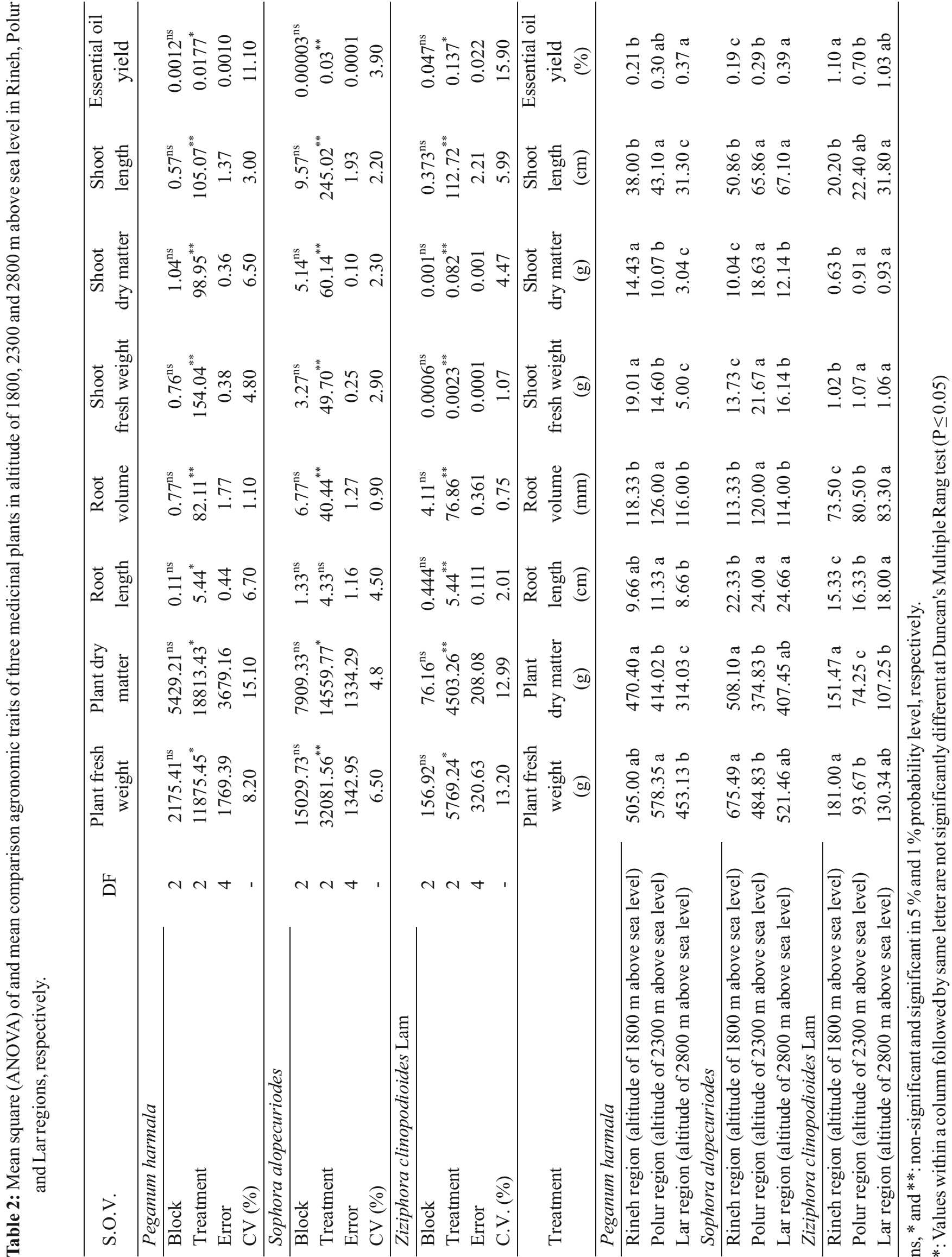


plant shoot was crushed by electric mill equal one kilogram to prepare the essential oil. The protocol for determining essential oil was presented by Jaymand and Rezaei (2006). Identification of essential oil components using inhibition time, calculating the Quartz index and studying mass spectra and comparing them with standard compounds and information contained in mass database (Adams, 2007).

\section{Statistical analysis}

After normalization, data analyzed by SAS statistical software and averages' comparison were calculated by Duncan's Multiple Range test in a 5\% probability level.

\section{RESULT AND DISCUSSION}

\section{Agronomic traits and essential oil efficiency}

Findings of analysis of variance (ANOVA) in Table 2 showed that all the investigated traits including plant fresh weight, plant dry matter, root length, root volume, shoot fresh weight, shoot dry matter, shoot length and essential oil yield for Peganum harmala and Ziziphora clinopodioides Lam were significant in $1 \%$ and $5 \%$ probability level on region (altitude) treatment. All agronomic traits except root length were significant in $5 \%$ and $1 \%$ probability level under the effect of region for Sophora alopecuriodes medicinal plant (Table 2).

Mean comparison of treatments demonstrated that shoot length of Peganum harmala in Polur region was $13.42 \%$ and $37.70 \%$ higher than Rineh and Lar regions, respectively. But, for Sophora alopecuriodes and Ziziphora clinopodioides, the most shoot length (67.1 and $31.8 \mathrm{~cm}$, respectively) was observed in Lar region and the minimum shoot length was obtained in Rineh region (Table 2). Similarly, root length of Peganum harmala in Polur region was $17.29 \%$ and $30.83 \%$ higher than Rineh and Lar regions, respectively. But, root length of for Sophora alopecuriodes in Polur and Lar regions was $7.48 \%$ and $10.43 \%$ higher than Rineh region. In addition, root length of Ziziphora clinopodioides in Lar region was $10.23 \%$ and $17.42 \%$ higher than Polur and Rineh regions, respectively (Table 2). The most root volume of Peganum harmala and Sophora alopecuriodes (126 and $120 \mathrm{~mm}$ ) was observed in Polur region and the lowest amount was achieved in Rineh and Lar regions. Root volume of Ziziphora clinopodioides in Lar region (83.3 mm) was 3.48\% and $13.33 \%$ higher than Polur and Rineh regions (Table 2).

Altitude mean comparison revealed that the highest shoot fresh weight and dry matter of Peganum harmala (19.01 and $14.43 \mathrm{~g}$, respectively) belonged to Rineh region, but the maximum amount of these traits in Sophora alopecuriodes (21.67 and $18.63 \mathrm{~g}$ ) was observed in Polur region. The minimum shoot fresh weight and shoot dry matter of Peganum harmala (5 and $3.04 \mathrm{~g}$ ) was achieved in Lar region. In addition, shoot fresh weight and shoot dry matter of Ziziphora clinopodioides in Polur and Lar regions was statistically higher than Rineh region (Table 2). The maximum plant fresh weight for Peganum harmala was observed in Polur region. But, plant fresh weight for Sophora alopecuriodes and Ziziphora clinopodioides in Rineh region got ranks first. In terms of plant dry matter, it observed that the most plant dry matter in all three medicinal plant was obtained in Rineh region, but the minimum plant dry matter of Peganum harmala was observed in Lar region (314.03 g) (Table 2). Based on the findings, it can be concluded that plant fresh weight and plant dry matter of all the three medicinal plant was decreased with enhance of altitude from sea level. Ghani et al. (2010) reported that with increasing altitude, plant growth period will be decreased and plant enters the reproductive stages more quickly. As a result, dry matter production decreases with increase of altitude. In fact, in natural ecosystems and agroecosystems, environmental factors such as humidity, water, nutrients, light, and altitude above sea level are among the main determinants of the plant qualitative and plant quantitative parameters. Considering the amount of nutrients and the amount of rainfall on the dry matter of Sophora alopecuriodes shows that the highest dry matter of this medicinal plant in altitude of $2300 \mathrm{~m}$ above sea level was higher than altitude of $1800 \mathrm{~m}$ above sea level due to the availability of sufficient nutrients, sufficient moisture and this plant adaptation in difficult condition.

Mean comparison showed that essential oil yield of Peganum harmala and Sophora alopecuriodes in Lar region was $23.33 \%$ and $34.48 \%$ higher than Polur region, as $76.19 \%$ and $105.26 \%$ more than Rineh region (Table 2). But, the essential oil yield of Ziziphora clinopodioides in Rineh region was 57.14\% and 6.8\% higher than Polur and Lar regions, respectively (Table 2). Thus, we can have concluded that essential oil yield of Peganum harmala and Sophora alopecuriodes enhanced by altitude increasing, but in Ziziphora clinopodioidest, with increase of altitude the essential oil yield was decreased.

\section{Medicinal qualitative parameters}

All qualitative parameters of Peganum harmala including neophytadiene, benzaldehyd 2-amino, quinazoline, deoxypeganine and eicosane were statistically significant 


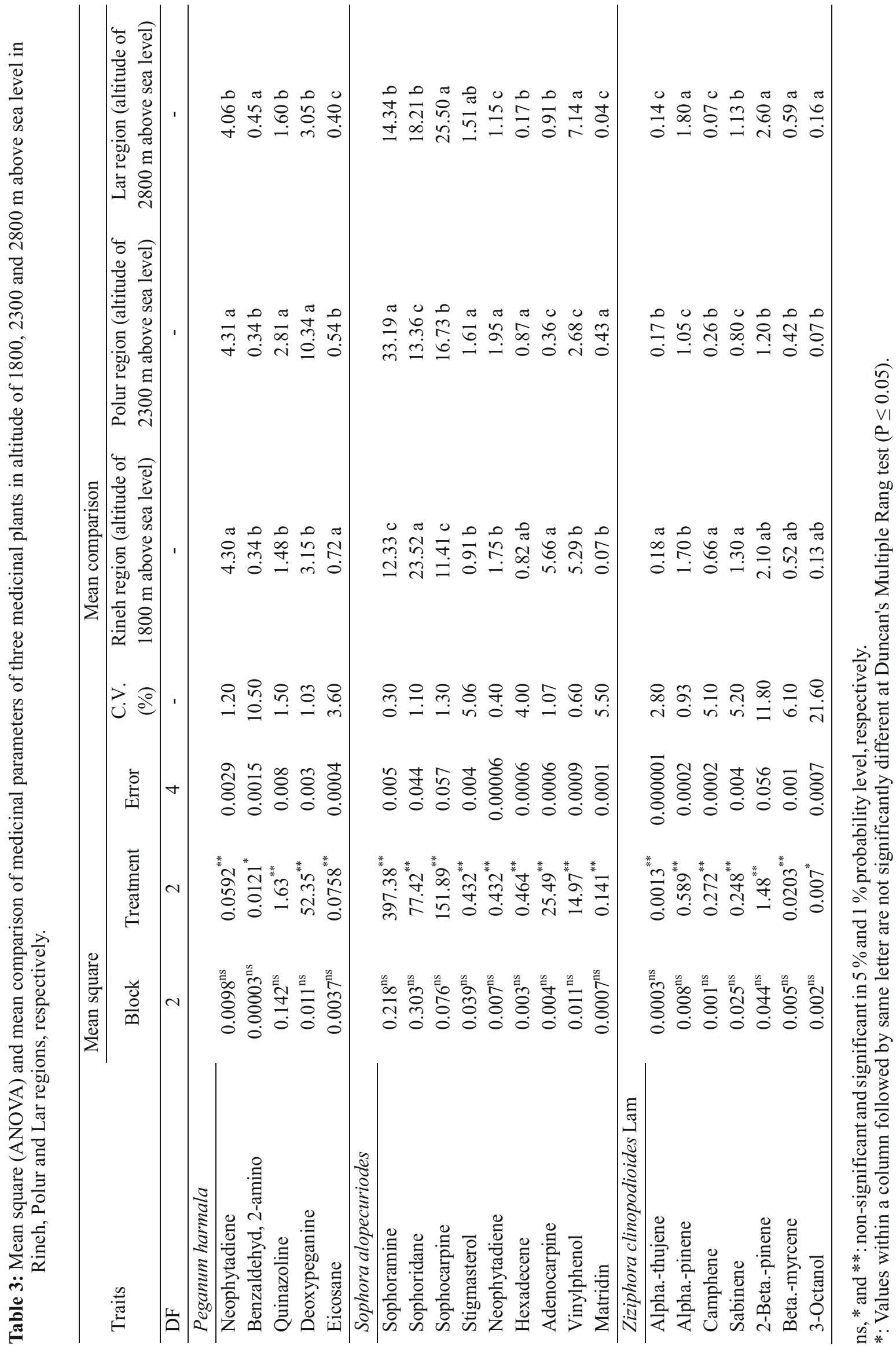


under altitude treatment level (Table 3). All investigated medicinal parameters of Sophora alopecuriodes which includes sophoramine, sophoridane, sophocarpine, stigmasterol, neophytadiene, hexadecene, adenocarpine, vinylphenol and matridin were statistically significant in $1 \%$ probability level. Furthermore, qualitative parameters of Ziziphora clinopodioides including alpha.-thujene, alpha.pinene, camphene, sabinene, 2-beta.-pinene, beta.-myrcene and 3-octanol were statistically significant under altitude treatment (Table 3).

Mean comparison of medicinal parameters of Peganum harmala revealed that neophytadiene in Rineh and Polur regions was statistically $5.91 \%$ and $6.16 \%$ higher than Lar region, respectively. But, benzaldehyd, 2-amino in Lar region statistically equals $32.35 \%$ was more than Rineh and Polur regions. Quinazoline and deoxypeganine in Polur region were significantly higher than Rineh and Lar regions. But, eicosane in Rineh region statistically was equals $33.33 \%$ and $80 \%$ greater than Polur and Lar regions (Table 3). Therefore, only benzaldehyd 2 -amino was enhanced with increase of altitude from $1800 \mathrm{~m}$ to $2800 \mathrm{~m}$ above sea level, but eicosane was decreased by altitude increasing. Other medicinal parameters of Peganum harmala showed the higher amounts in altitude of $2300 \mathrm{~m}$ above sea level.

According to the findings, Sophora alopecuriodes demonstrated that the maximum sophoramine, stigmasterol, neophytadiene, hexadecene, and vinylphenol in Polur region was statistically higher than Rineh and Lar regions, moreover, the least amount of sophoramine and stigmasterol was obtained in Rineh region (Table 3). The highest rate of sophocarpine and adenocarpine for Sophora alopecuriodes was obtained in Rineh region. (Table 3). The most amount of sophoramine and adenocarpine was obtained in $1800 \mathrm{~m}$ above sea level, but sophocarpine and vinylphenol shows the highest rates in $2800 \mathrm{~m}$ above sea level. Other medicinal parameters revealed the higher amount in $2300 \mathrm{~m}$ above sea level.

According to mean comparison, medicinal parameters of Ziziphora clinopodioides including alpha.-thujene, camphene, and sabinene in Rineh region significantly was higher than Polur and Lar regions. But, alpha.-pinene, 2-beta.pinene, beta.-myrcene and 3-octanol in Lar region statistically were higher than Rineh and Polur regions (Table 3). Assessing the Ziziphora clinopodioides medicinal parameters demonstrated that the highest amount of alpha.-thujene, camphene and sabinene was observed in altitude of $1800 \mathrm{~m}$ above sea level. But, alpha.-pinene, 2-beta.-pinene, beta.- myrcene and 3-octanol in altitude of $2800 \mathrm{~m}$ above sea level demonstrated higher rates.

In recent years, studies on Sophora alopecuriodes have gradually increased (Chang et al. 2014). Alkaloids of sophora are widely used in clinical settings and have good biological activities (Chang et al. 2014). Studies have also found that TASA have a broad-spectrum anti-bacterial activity, and can induce apoptosis of hepatoma SMMC-7721, cells in Sophora (Ye et al. 2009). Some sophora species are commonly used in traditional Chinese medicine which includes the roots of $S$. flavescens, the roots of $S$. tonkinensis, and the seeds of $S$. alopecuroides. Sophora species are known to contain quinolizidine alkaloids (QAs) as their principal bioactive constituents. More than 20 kinds of alkaloids have been isolated from the plant including sophoramine, cytosine, oxymartin, sophocarpine, martine, oxysophocarpine, nicotine and others. The alkaloids have shown antimicrobial, cardiovascular, gastrointestinal, immunological, and anticancer effects in the pharmacological studies ( $\mathrm{Lu}$ et al. 2014; Chang et al. 2014).

Many pharmacological surveys have shown different effects of $P$. harmala and/or its active alkaloids. Studies carried out on the chemical composition of the extracts show that beta-carboline and quinazoline alkaloids are important compounds of this plant. In one study, the concentration of harmaline in different parts of the plant including seeds, fruits, and capsule walls was determined by reverse phase highperformance liquid chromatography (RP-HPLC) as $56.0 \mathrm{mg} \mathrm{g}$ ', $4.55 \mathrm{mg} \mathrm{g}^{-1}$ and $0.54 \mathrm{mg} \mathrm{g}^{-1}$, respectively (Herraiz et al. 2010). Harmaline (C13H15ON2) was first isolated by Gobel from the seeds and roots of $P$. harmala and is the major alkaloid of this plant. In addition to $P$. harmala (Harmal), beta-carboline alkaloids are present in many other plants such as Banisteriopsis caapi (Malpighiaceae). They are also constituents of ayahuasca, a hallucinogenic beverage ingested in rituals by the Amazonian tribes (Herraiz et al. 2010).

Dehghan et al. (2014) showed that the essential oil yield of Ziziohora tenuior in Hamadan province, Iran was between 0.37 to $1 \%$ and the amount of pulegone and 1,8cineole as components essential oils are varied in different rangelands. These results were consistent with other researchers' findings (Jafari, 2002; Eftekhar et al. 2005).

Much of the biological activity of Ziziphora clinopodioide Lam has been reported, such as its antibacterial, antimicrobial and antioxidant properties, its relaxing effect on the vascular system and its immunity-boosting effect on laying 
hens (Ali et al. 2012; Soltani, 2012). Tian et al. (2011) determined the oleanolic and ursolic acid content in the plant by using the high-performance liquid chromatography. Yu et al. (2012) established the quality standard of ziziphora. Yu et al. (2012) the changes in the chemical composition of ziziphora. Throughout different growth stages have not been reported and the harvest date affects the chemical composition of the plant.

\section{CONCLUSION}

This study was undertaken to determine the dynamic changes of chemical composition of ziziphora in different growth stages and its optimum harvest time when grown at different altitudes. According to findings, plant fresh weight and plant dry matter of Peganum harmala, Sophora alopecuriodes and Ziziphora clinopodioides decreased with increase in altitude. Essential oil yield of Peganum harmala and Sophora alopecuriodes increased with altitude, but decreased for Ziziphora clinopodioidest. For Peganum harmala, only benzaldehyd 2-amino was enhanced with increase in altitude from $1800 \mathrm{~m}$ to $2800 \mathrm{~m}$, but other medicinal parameters were higher in altitude of $2300 \mathrm{~m}$. For Sophora alopecuriodes, the maximum amount of sophoramine and adenocarpine were obtained in $1800 \mathrm{~m}$ AMSL, whereas sophocarpine and vinylphenol showed the highest rate in $2800 \mathrm{~m}$. For Ziziphora clinopodioides, the highest amount of alpha.-thujene, camphene and sabinene were observed in altitude of $1800 \mathrm{~m}$. This clearly shows that, natural ecosystems and altitude are among the main determinants of the qualitative and quantitative parameters of medicinal plants. However, further investigation needs to be carried out to quantify the altitudinal effect in terms of various meteorological parameters on the qualitative and quantitative performances of the medicinal plants.

\section{REFERENCES}

Adams, R.P. (2007). Identification of essential oil components by Gas Chromatography/Mass Spectrometry, $4^{\text {th }}$ Edition, Allured Publishing Corporation. USA, 804p.

Ali, N., Navid, H.M. and Mohanmmad, A.M. (2012). Effect of Melissa officinalis L., Tanacetum balsamita L. and Ziziphora clinopodioides L. on performance, blood biochemical and immunity parameters of Laying Hens. Asian J. Anim. Vet. Adv. 7: 74-79.

Berdai, M.A., Labib, S. and Harandou, M. (2014). Peganum harmala L. Intoxication in a Pregnant Woman. Case Reports in Emergency Medicine. 3: http://dx.doi.org/10.1155/2014/783236

Chang, A., Cai, Z., Wang, Z. and Sun, S. (2014). Extraction and isolation of alkaloids of Sophora alopecuroides and their anti-tumor effects in H22 tumor-bearing mice. Afr. J. Tradit. Compl. Altern. Med., 11:245-248.

Dehghan, Z., Sefidkon, F., Emami, S.M. and Kalvandi, R. (2014). The effects of ecological factors on essential oil yield and composition of Ziziphora clinopodioides Lam. Subsp. rigida (Boiss). J. Plant Res., 27(1): 49-63.

Ding, W., Yang, T., Liu, F. and Tian, S. (2014). Effect of different growth stages of Ziziphora clinopodioides Lam. on its chemical composition. Pharmacogn Mag, 10: (Suppl 1): S1-S5.

Eftekhar, F., Salehi, P., Sonboli, A., Nejad Ebrahimi, S. and Yousef Zadi, M. (2005). Essential oil composition, antibacterial and antioxidant activity of oils and various extracts of Ziziphora clinopodioides subsp rigida (Boiss) from Iran. Biol. Pharm. Bull., 28: 8921896.

Ghani, A., Ebrahimpour, A., Tehranifar, A. and HassanzadehKhayyat, M. (2010). Evaluation of growth and development adaptability and medicinal-ornamental potential of Clary sage (Salvia sclarea L.) cultivated in Mashhad climatic conditions. J. Plant Prod., 17(1): 7790.

Herraiz, T., González, D., Ancín-Azpilicueta, C., Aran, V.J. and Guillen, H. (2010). Beta-Carboline alkaloids in Peganum harmala and inhibition of human monoamine oxidase (MAO). Food Chem. Toxicol., 48: 839-45.

Jafari, M. (2002). Antimicrobial effects of essential oils and extracts on Helicobacter Pylori Mountain Ziziphora tenuior, Thesis, School of Pharmacy, Mashhad University of Medical Sciences.

Jaymand, K. and Rezai, M.B. (2006). Essential oil, distillation devices, test methods and retention indices in essential oil analysis. Community medicinal plant of Iran press. Tehran. 350 p.

Kianbakht, S. and Hajiaghaee, R. (2014). Effects of Sophora alopecuroides L. Zingiber officinale Rosc. and Melissa officinalis L. in formalin and straub tail tests. J. Med. Plant., 13:33-40.

Kianbakht, S. and Hashem Dabaghian, F. (2016). Sophora 
alopecuroides L. var. alopecuroides alleviates morphine withdrawal syndrome in mice: involvement of alkaloid fraction and matrine. Iran J. Basic Med. Sci., 19(10): 1090-1095.

Liu, Y.M. (1985). Xinjiang: Science and Technology Health Publisher. Pharmacography of Uighur; pp. 353-337.

Lu, X., Lin, B., Tang, J.G., Cao, Z. and Hu, Y. (2014). Study on the inhibitory effect of total alkaliods of Sophora alopecuroides on osteosarcoma cell growth. Afr. J. Tradit. Compl. Altern. Med., 11: 172-175.

Maya, B. (2011). The Evaluation of Medicinal Properties of Ziziphora clinopodioides. World Appl. Sci. J., 9: 16358.

Mozaffarian, V. (2013). Identification of medicinal and aromatic plants of Iran. Farhang Moaser. Iran, 850.8502013 .
Soltani, N.S. (2012). Chemical composition and in vitro antibacterial activity of Ziziphora clinopodioides Lam. essential oil against some pathogenic bacteria. Afr. J. Microbiol. Res., 7: 1504-1508.

Tian, S., Shi, Y., Zhou, X., Ge, L. and Upur, H. (2011). Total polyphenolic (flavonoids) content and antioxidant capacity of different Ziziphora clinopodioides Lam. extracts. Pharmacogn. Mag., 7:65-68.

Wanntorp, L. and Louis, P. (2011). Swedish museum of natural history. In: Wanntorp L, editor. Flowers on the Tree of Life. Series: Systematics Association Special Volume

Ye, G., Ma, C.H., Huang, X.Y., Li, Z.X. and Huang, C.G. (2009). Components of Sophora alopecuroides Seeds. Chem. Nat. Comp., 45(4): 545-546.

Yu, Q., Halmuart, U. and Xin, L.D. (2012). Chemical Fingerprinting by RP-RRLC-DAD and principal component analysis of Ziziphora clinopodioides Lam from different locations. Nat. Prod. Commun., 9: 11811184. 